\title{
The Strategy of South Korea in the Global Oil Market
}

\author{
Jaehyung An ${ }^{1} \mathbb{D}$, Alexey Mikhaylov ${ }^{2, *} \mathbb{C}$ and Sang-Uk Jung ${ }^{1}$ \\ 1 College of Business, Hankuk University of Foreign Studies, Seoul 02450, Korea; \\ jaehyung.an@hufs.ac.kr (J.A.); sanguk.jung@hufs.ac.kr (S.-U.J.) \\ 2 Financial University under the Government of the Russian Federation, Moscow 124167, Russia \\ * Correspondence: ayumihajlov@fa.ru; Tel.: +7-901-908-9817
}

Received: 13 April 2020; Accepted: 11 May 2020; Published: 15 May 2020

\begin{abstract}
The paper analyzes South Korea's strategy in the global oil market. South Korean oil cooperation is characterized by the creation or termination of joint projects in the oil sector, as well as the Republic of Korea's national project for the diversification of state-energy suppliers. Oil cooperation currently has great potential, and the conditions that have developed at the highest level allow open discussions about positive dynamics for short-term and medium-term prospects in the field of oil cooperation. The analysis presented here includes export and import connections in the oil market. The authorities of the current administration of the Republic of Korea have adopted a new political stance towards the north, in accordance with which the state is actively developing and establishing relations with the Democratic People's Republic of Korea (DPRK) and the Russian Federation. In the coming years, South Korea aims to renew and revise potential projects in the field of oil cooperation. The main result of this is that the political climate of the Republic of Korea is currently concentrated on the development of an oil cooperation strategy.
\end{abstract}

Keywords: game theory; South Korea; oil policy; resource saving; economic development; oil cooperation

\section{Introduction}

The current global oil market satisfies the main participants in market relations, which significantly reduces the risks of emerging "resource wars". States are more eager to cooperate in the oil sector than to enter conflict with each other.

Certain points of discussion in this field have been identified, including doubts which are rooted in the environment of South Korean business regarding the nature of the Russian economy; i.e., the remnants of the USSR's planned economy, which do not guarantee security for foreign businesses in Russia. The degree inaccessibility of the country (primarily from a linguistic point of view) is not reliable, and there is an absence of detailed information regarding various taxes, customs and other procedures. These problems are also relevant to other states' economic cooperation.

In general, if we are to discuss historiography on the topic of oil cooperation, it is worth noting that little attention is currently being devoted to this topic. Little attention has been paid to this subject, and few research works have been conducted, as oil cooperation itself originated relatively recently-it has only been in place since 1993. Most studies have focused on the economic aspect of state cooperation and the concept of oil security.

Russian oil policy during the third-term government of President Putin aims at the prospective development of oil production in the Far Eastern region. The paper considers the dynamics of oil exports and joint projects to develop cooperation in this sphere and analyzes changes in the officially developed oil strategies. 


\section{Literature Review}

The concept of oil security determines the foreign policy of the Russian Federation; thus, we are able to state that oil security is a priority for the Russian Federation as an exporting state [1-4].

The authors have also turned their attention to the works of the most prominent representatives of neoliberalism in order to explain the behavior of states in the field of oil cooperation [5-7].

Another important comprehensive study that represents the concept of oil security and the oil cooperation phenomenon in terms of various theoretical approaches is the "Energy Studies in the Theory of International Relations" [8-10]. Thanks to this work, it was possible to conduct detailed research into the currently existing theoretical developments regarding the phenomenon of state cooperation in oil [11-13]. The authors use this as an indication of the official energy strategy of the Russian Government as well as various developments, in combination with studies by Russian and foreign - mainly of Korean origin — scientists on the topic of oil cooperation and security [14-16].

This concept reflects the official position of the state regarding oil cooperation, which aims to diversify importers, expand exports to the Asia-Pacific region and develop oil infrastructure projects in Siberia and the Far East [17-19].

Based on this, conclusions were drawn that oil cooperation with Korea has a very high potential, the development of which will be given significant attention. Moon Jae In's "New Northern Policy" was also seen as a key source of oil cooperation, which is led by the South Korea at this stage [20-23].

This oil policy is reflected in an official speech by Moon Jae In at the Third Eastern Economic Forum, which included priority areas that will improve the process of developing cooperation with the Russian Federation, including in oil and infrastructure areas. Based on the analysis of the President's speech, conclusions were drawn about the complementarity of Russian and Korean oil cooperation strategies, as well as the presence of mutual interest in deepening cooperation [24-26].

\section{Methods}

In order to identify the dynamics of the development of oil cooperation, an event analysis method was held at the highest framework levels of various forums and department meetings related to oil cooperation between the Republic of Korea and the Russian Federation. The content analysis method was used when working with various documents related to states' oil cooperation, such as treaties, agreements, memoranda, as well as the speech of South Korean President Moon Jae In during the opening ceremony of the Third Eastern Economic Forum.

Consent to cooperation or its refusal are used to explain macroeconomics with respect to cooperation $[27,28]$. The game theory is based on the assumption that the decision-making parties act rationally (Figure 1; Figure 2) [29-31].

During the writing of the work, Thomson Reuters and Worldmeters were used to compile figures showing export and import volumes of energy resources [32-34].

Thus, when conducting research and writing work, the following sources and literature were used: statistical databases, treaties and agreements, official speeches, official state strategies and policies, energy research, and information provided on news portals and government sites [35-37].

During the study, the authors of this work made assumptions based on the complementary nature of the economies of the Republic of Korea and the Russian Federation, considering that, in the current political climate, sufficient effort is made by both parties. 


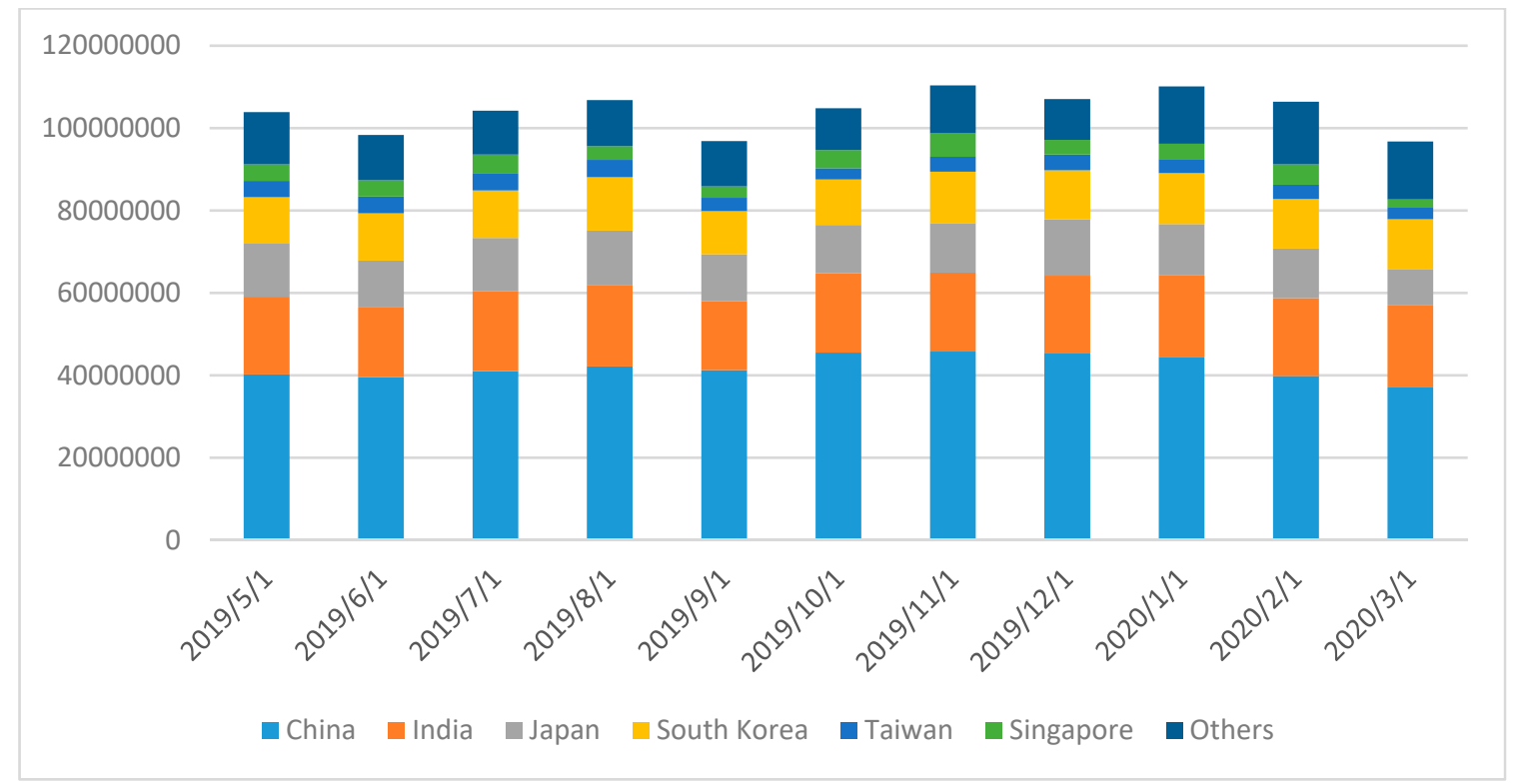

Figure 1. Asian crude oil imports by demand countries, USD [38].

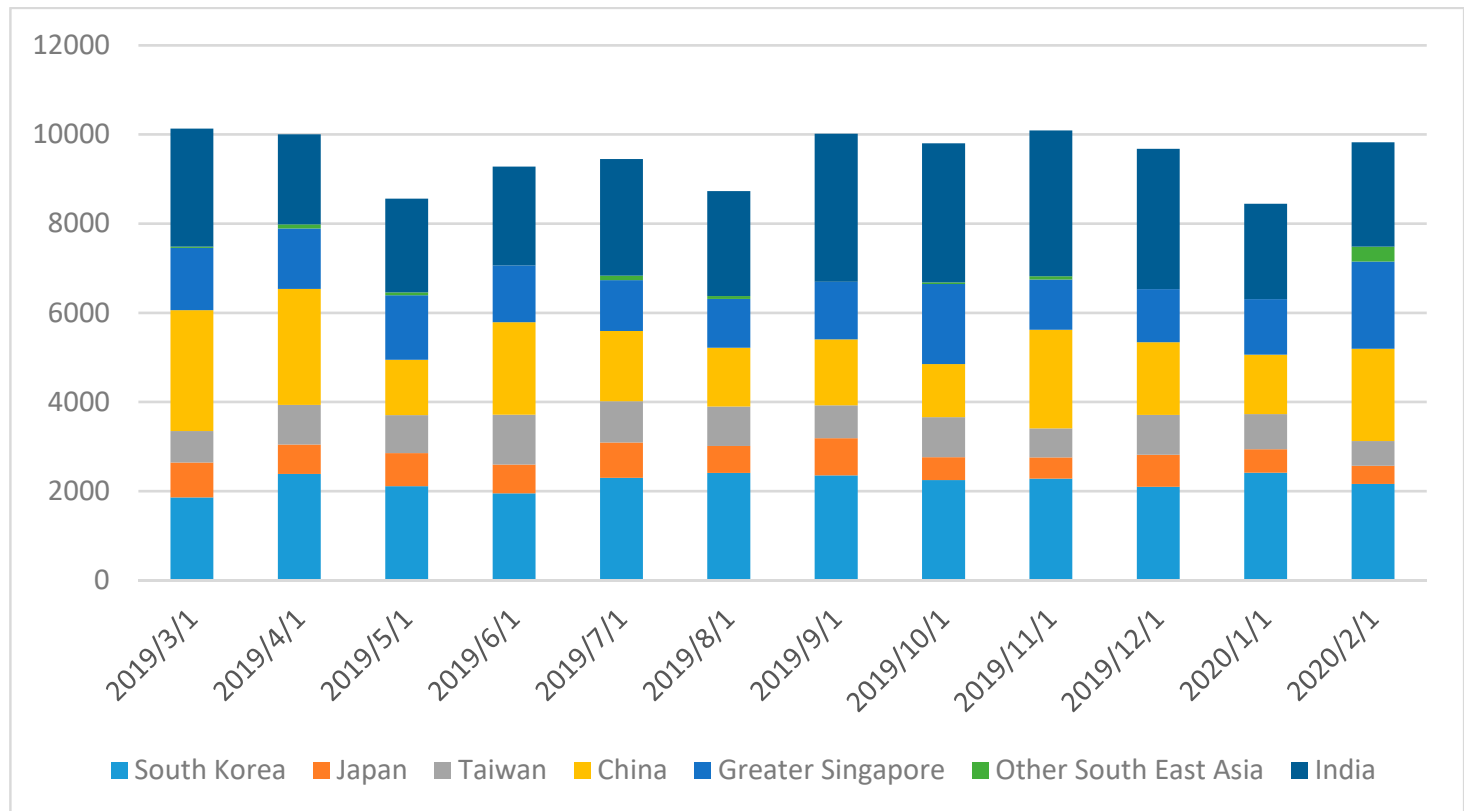

Figure 2. Asian gasoil exports by supply countries, USD [38].

\section{Results}

State oil cooperation is only one application area of this theory. In the case of oil-exporting countries, states are interested in ensuring the most profitable terms of export of their resources and the stability of demand of economic goods.

As part of this section, the second type of games will be considered-games with a non-zero sum-along with their subspecies. A classic example of applying the game theory method is the "prisoners' dilemma", where players, seeking to maximize their benefits, choose a strategy of either cooperating with each other or abandoning cooperation [39,40].

In the framework of the dilemma, there are four standard scenarios, presented in the form of a matrix table below (Table 1). 
Table 1. Matrix of solutions for the "prisoners' dilemma" in the field of state cooperation.

\begin{tabular}{ccc}
\hline & Cooperation & Non-Cooperation \\
\hline Cooperation & Joint decision & "A" imposes its will “B” \\
\hline Non-cooperation & B imposes its will "A" & Status quo \\
\hline
\end{tabular}

The result of the interaction is not equally favorable for the parties. If both states refuse cooperation, they apparently prefer to maintain their current position as unchanged maintaining the status quo. These three scenarios are one of the varieties of the game with a nonzero sum called a non-cooperative game [41].

The outcome which is mutually beneficial for both parties is possible under the scenario in which both states are open and willing to cooperate. In this case, the states jointly develop cooperation projects that fully take into account the interests of the other party. This collaboration scenario applies to a cooperative subspecies of a game with a nonzero sum (Figure 3; Figure 4).

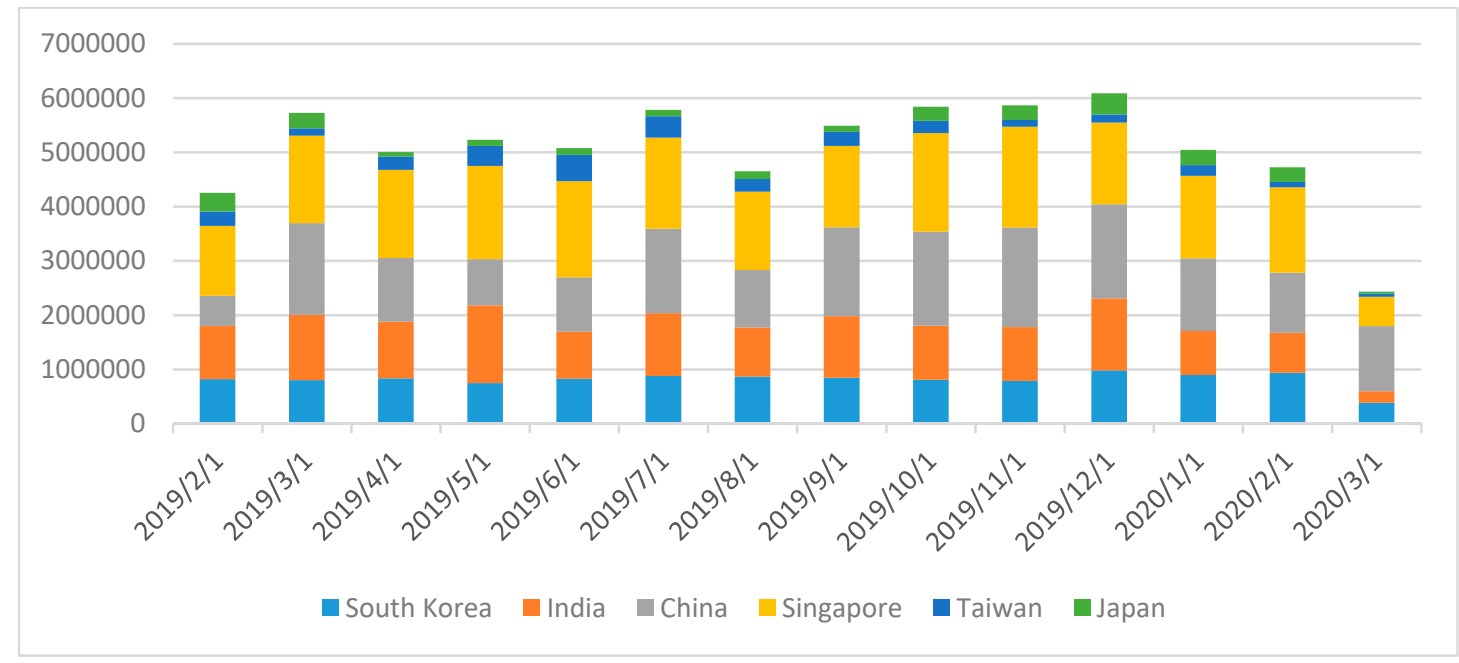

Figure 3. Total Asian oil demand by source, USD [38].

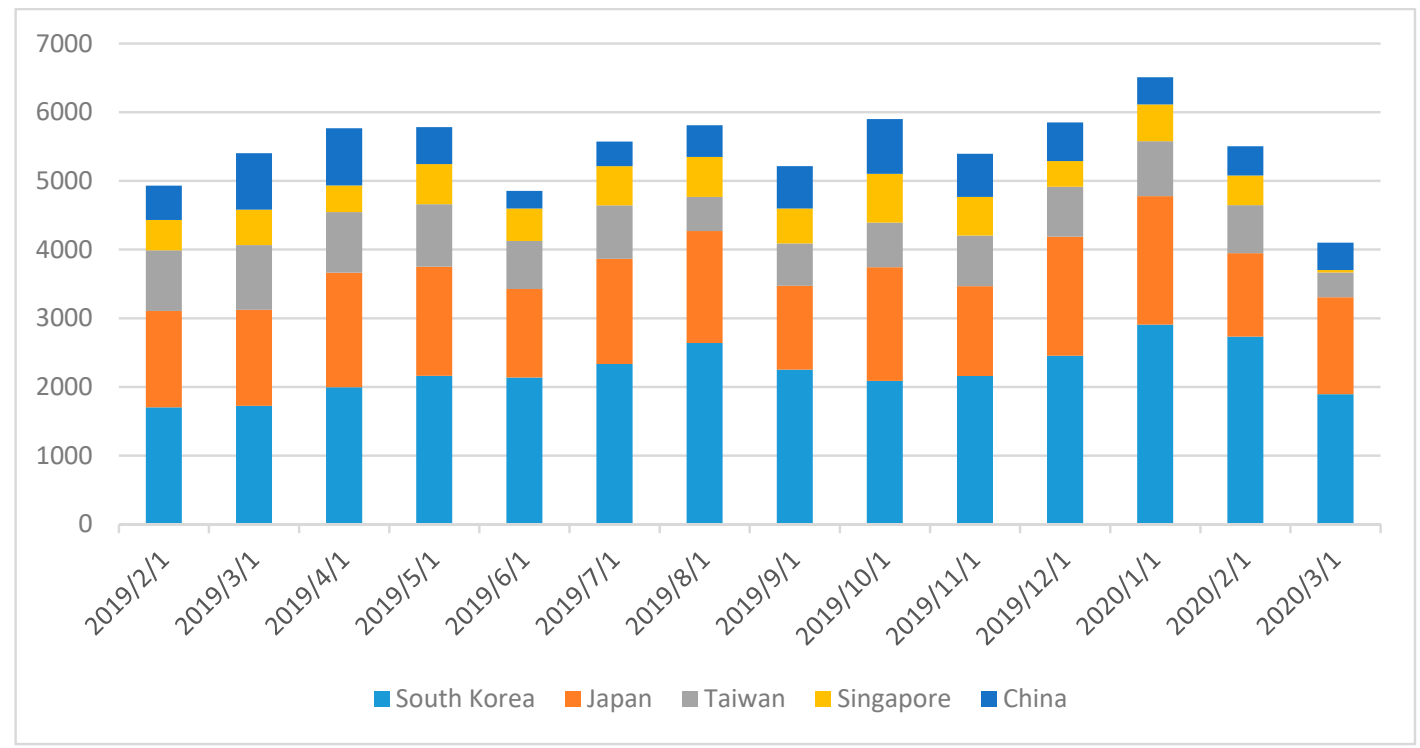

Figure 4. Asian oil exports by country, USD [38]. 


\section{Discussion}

The interpretation of global oil processes, including oil cooperation, is carried out mainly in the framework of the neorealistic approach in international relations, which is based on the struggle of states for energy resources.

Returning to game theory, war is a game with a non-zero sum [42-44]. Proponents of the neoliberal approach are inclined to believe that the diversity of players in international relations minimizes the risk of military confrontation between states in the struggle for energy resources and contributes to peaceful cooperation and the development of global regulation in the oil sector $[45,46]$.

The following is an example of this approach: state interaction in the oil sector is mainly based on national interests [47-49]. Neorealism assumes that oil cooperation and the oil policies of states are dictated by purely national interests and expressed in military confrontation in the struggle for resources. The national interest of importing countries is committed to providing access to energy [50-52].

There is a stable supply of oil. The main interests in the case of exporting countries are maximum profits and political benefits from the fuel and oil trade. Political benefits in this arena mean the ability to influence states that depend on oil supplies. The competition for ever-decreasing oil resources is leading to the creation of interstate alliances, which in turn provoke confrontations on different levels-local, regional and global. Therefore, it is possible to conclude that neorealism denies the mutually beneficial oil cooperation of states as one of the most likely forms of state behavior on the world stage, in which only national interests are predominantly pursued [53-55].

The neoliberal approach shows that oil cooperation between the Russian Federation and the Republic of Korea can be largely defined by existing interdependencies. For example, the dependence of the Republic of Korea on oil supply poses a significant risk to the South Korean economy and oil-based industries. In the case of interruptions of deliveries from the main South Korean oil exporters-the Middle Eastern countries-Korea will need time to restore the production processes, for example, of its refineries. To reduce such risks, Korea will seek to diversify their structure of oil imports, meaning that the Russian Federation can become one of its leading exporters due to their geographical location [56-58].

Furthermore, the Russian Federation is interested in developing cooperation in the Far East, which the prosperity of this region depends on. Moreover, the welfare of the Russian economy depends directly on the establishment of exports of oil resources and the price of this. While European states have traditionally occupied a leading position in the structure of Russian oil imports, recent events-namely anti-Russian sanctions-have negatively affected the economy [59-61].

Therefore, for Russia, as well as for Korea, it is important that Korea should diversify its imports in order to reduce its dependence on the export of oil resources and ensure the oil security of the state.

Oil shortages do not necessarily lead to confrontation and fierce competition, and focusing on rivalry as the most likely model behavior of states does not allow us to cover all possible oil interactions of states [62-64].

The neoliberal approach to oil cooperation developed particularly at the end of the 1970s: at this time, the truly global and competitive oil market had begun to emerge and prosper [65-67].

\section{Conclusions}

Although the problems we are facing today are also serious in comparison to, for example, a decade ago, it is precisely today that the most favorable political conditions for fostering an active interaction and dialogue between parties are present, which will allow states in the short and medium-term to significantly strengthen and expand oil cooperation.

North Korea and the Russian Federation have the desire and willingness to interact with other states-a policy which is determined primarily by political factors.

Under previous South Korean administrations, emphasis was placed on cooperation and active interaction with the United States, partly to the detriment of Russian-South Korean cooperation, and to the detriment of relations in the Korean peninsula. 
The permanent joint exercises of the USA and Korea near the borders of the DPRK have constantly provoked the latter to retaliate in the form of regular nuclear tests and intercontinental ballistic missile launches. In such a tense environment, the further development and deepening of oil cooperation between the Republic of Korea and the Russian Federation seemed almost impossible, as this required the involvement of North Korean parties to implement such grandiose projects as the Trans-Korean gas pipeline and Trans-Korean railway, without the implementation of which the transition to a new, more high-quality and deep level of oil cooperation would not be possible.

The active participation of both parties in the implementation of joint infrastructure and the closely related oil and gas projects includes constant interaction with business representatives, government departments and oil-related corporations such as KOGAS, KNOC, Gazprom and Rosneft, as well as Russian Railways. Regarding oil cooperation in the long term, it is difficult to draw any definite conclusions; from the experience of past years, it can be judged that, with the advent of the new administration in the Republic of Korea, everything could change radically, and the actively developing cooperation with the Russian Federation and the DPRK may be abruptly interrupted.

Author Contributions: Conceptualization, J.A. and A.M.; methodology, A.M.; software, A.M.; validation, J.A.; formal analysis, S.-U.J.; investigation, A.M.; resources, A.M.; data curation, A.M.; writing-original draft preparation, A.M.; writing - review and editing, A.M.; visualization, J.A.; supervision, A.M.; project administration, A.M.; funding acquisition, S.-U.J. All authors have read and agreed to the published version of the manuscript.

Funding: The first and the third authors were supported by the Hankuk University of Foreign Studies Research Fund.

Conflicts of Interest: The authors declare no conflict of interest.

\section{References}

1. Hamilton, J.D. This is what happened to the oil price-macroeconomy relationship. J. Monet. Econ. 1996, 38, 215-220. [CrossRef]

2. Hamilton, J.D. What is an oil shock? J. Econom. 2003, 113, 363-398. [CrossRef]

3. Hamilton, J.D. Nonlinearities and the Macroeconomic Effects of Oil Prices; NBER Working Papers; National Bureau of Economic Research, Inc.: Cambridge, MA, USA, 2010; pp. 161-186.

4. Bernanke, B.S.; Gertler, M.; Watson, M. Systematic monetary policy and the effects of oil price shocks.Brook. Pap. Econ. Act. 1997, 1, 91-142. [CrossRef]

5. Hamilton, J.D.; Herrera, A.M. Oil shocks and aggregate macroeconomic behavior: The role of monetary policy: Comment. J. Money Credit Bank. 2004, 36, 265-286. [CrossRef]

6. Bernanke, B.S.; Gertler, M.; Watson, M.W. Oil shocks and aggregate macroeconomic behavior: The role of monetary policy: Reply. J. Money Credit Bank. 2004, 36, 287-291. [CrossRef]

7. Sanya, O. Oil Prices and Nigerian Aggregate Economic Activities. IOSR J. Econ. Financ. 2015, 6, 65-72.

8. Kilian, L. Exogenous Oil Supply Shocks: How Big Are They and How Much Do They Matter for the US Economy? Rev. Econ. Stat. 2008, 90, 216-240. [CrossRef]

9. Matsumoto, K.; Andriosopoulos, K. Energy security in East Asia under climate mitigation scenarios in the 21st century. Omega 2016, 59, 60-71. [CrossRef]

10. Lin, B.; Chunping, X. Estimation on oil demand and oil saving potential of China's road transport sector. Energy Policy 2013, 61, 472-482. [CrossRef]

11. Kilian, L. Not all oil price shocks are alike: Disentangling demand and supply shocks in the crude oil market. Am. Econ. Rev. 2009, 99, 1053-1069. [CrossRef]

12. Charfeddinea, L.; Klein, T.; Walther, T. Oil Price Changes and U.S. Real GDP Growth: Is this Time Different; University of St. Gallen: St. Gallen, Switzerland, 2018.

13. Nicholas, A.; Miller, S. Do structural oil-market shocks affect stock prices? Energy Econ. 2009, 31, 569-575.

14. Basher, S.A.; Sadorsky, P. Oil price risk and emerging stock markets. Glob. Financ. J. 2006, 17, $280-292$. [CrossRef]

15. Aloui, C.; Nguyen, D.K.; Njeh, H. Assessing the Impacts of Oil Price Fluctuations on Stock Returns in Emerging Markets. Econ. Model. 2012, 29, 2686-2695. [CrossRef] 
16. Kilian, L.; Park, C. The Impact of Oil Price Shocks on the U.S. Stock Market; CEPR Discussion Paper; Centre for Economic Policy Research: London, UK, 2007.

17. Filis, G.; Degiannakis, S.; Floros, C. Dynamic correlation between stock market and oil prices: The case of oil-importing and oil-exporting countries. Int. Rev. Financ. Anal. 2011, 20, 82-94. [CrossRef]

18. Li, S.F.; Hui-Ming, Z.; Keming, Y. Oil prices and stock market in China: A sector analysis using panel cointegration with multiple breaks. Energy Econ. 2012, 34, 102-134. [CrossRef]

19. Rangan, G.; Modise, M.P. Macroeconomic Variables and South African Stock Return Predictability. Econ. Model. 2012, 30, 612-622.

20. Awartani, B.; Maghyereh, A.I. Dynamic spillovers between oil and stock markets in the Gulf Cooperation Council Countries. Energy Econ. 2012, 36, 28-42. [CrossRef]

21. Amano, R.A.; Van Norden, S. Oil prices and the rise and fall of the US real exchange rate. J. Int. Money Financ. 1998, 17, 299-316. [CrossRef]

22. Akram, Q.F. Oil prices and exchange rates: Norwegian evidence. Econom. J. 2004, 7, 476-504. [CrossRef]

23. Yousefi, A.; Wirjanto, T.S. The empirical role of the exchange rate on the crude-oil price formation. Energy Econ. 2004, 26, 783-799. [CrossRef]

24. Buetzer, S.; Habib, M.; Stracca, L. Global Exchange Rate Configuration. In Do Oil Shocks Matter; ECB Working Paper Series No. 1442; The European Central Bank: Frankfurt/Main, Germany, 2012.

25. Chen, Y.; Rogoff, K.; Rossi, B. Can Excha.ge Rates Forecast Commodity Prices? Q. J. Econ. 2010, 125, 1145-1194. [CrossRef]

26. Buetzer, S.; Habib, M.; Stracca, L. Plummeting oil prices, depreciating oil currencies? Not that simple. Q. J. Econ. 2010, 125, 1145-1194.

27. Cifarelli, G.; Paladino, G. Oil price dynamics and speculation: Amultivariate financial approach. Energy Econ. 2010, 32, 363-372. [CrossRef]

28. Bekiros, S.D.; Diks Cees, G.H. The relationship between crude oil spot and futures prices: Cointegration, linear and nonlinear causality. Energy Econ. 2008, 30, 2673-2685. [CrossRef]

29. Ramazan, S.; Hammoudeh, S.; Soytas, U. Dynamics of oil price, precious metal prices, and exchange rate. Energy Econ. 2010, 32, 351-362.

30. Engle, R.; Granger, C. Co-integration and error correction: Representation, estimation, and testing. Econometrica 1987, 55, 251-276. [CrossRef]

31. Banerjee, A.; Dolado, J.J.; Gailbraith, J.W.; Hendry, D.F. Co-Integration, Error-Correction, and the Econometric Analysis of Non-Stationary Data, Advanced Texts in Econometrics; Oxford University Press: Oxford, UK, 1986.

32. Asteriou, D.; Hall, S.G. Applied Econometrics, rev. ed.; Red Globe Press: London, UK, 2007; p. 552.

33. Aliyev, K.H.; Dehning, B.; Nadirov, O. Modelling the impact of fiscal policyon non-oil GDP in a resource rich country: Evidence from Azerbaijan. Acta Univ. Agric. Silvic. Mendel. Brun. 2016, 64, 1869-1878. [CrossRef]

34. Liu, Y.; Dong, H.; Failler, P. The Oil Market Reactions to OPEC's Announcements. Energies 2019, 12, 3238. [CrossRef]

35. Humbatova, S.; Hajiyev, N. Oil Factor in Economic Development. Energies 2019, 12, 1573. [CrossRef]

36. Alwaelya, S.A.; Yousif, N.B.A.; Mikhaylov, A. Emotional Development in Preschoolers and Socialization. Early Child Dev. Care 2020, 190, 3. [CrossRef]

37. An, J.; Dorofeev, M.; Zhu, S. Development of Energy Cooperation Between Russia and China. Int. J. Energy Econ. Policy 2020, 10, 134-139. [CrossRef]

38. Worldmeters. Available online: https://www.worldometers.info/energy/south-korea-energy (accessed on 1 April 2020).

39. An, J.; Dorofeev, M. Short-term FX forecasting: Decision making on the base of expert polls. Invest. Manag. Financ. Innov. 2019, 16, 72-85. [CrossRef]

40. Balestra, P.; Nerlove, M. Pooling gross section and time series data in the estimation of a dynamic model: The demand for natural gas. Econometrica 1966, 34, 585-612. [CrossRef]

41. Blanchard, L. The production and inventory behavior of the American automobile industry. J. Political Econ. 1983, 91, 365-400. [CrossRef]

42. Branch, E. Short run income elasticity of demand for residential electricity using consumer expenditure. Energy J. 1993, 14, 111-121.

43. Brown, M. Market failures and barriers as a basis for clean energy policies. Energy Policy 2001, 29, 1197-1207. [CrossRef] 
44. Cameron, T.A. A nested logit model of energy conservation activity by owners of existing single family. Rev. Econ. Stat. 1985, 67, 205-211. [CrossRef]

45. Davis, L. Durable goods and residential demand for energy and water: Evidence from a field trial. RAND J. Econ. 2008, 39, 530-546. [CrossRef]

46. Davis, L. Evaluating the slow adoption of energy efficient investments: Are renters less likely to have energy efficient appliances? In The Design and Implementation of US Climate Policy; University of Chicago Press: Chicago, IL, USA, 2011; pp. 301-316.

47. Dayong, N.; Mikhaylov, A.; Bratanovsky, S.; Shaikh, Z.A.; Stepanova, D. Mathematical modeling of the technological processes of catering products production. J. Food Process Eng. 2020, 43, 2. [CrossRef]

48. Denisova, V.; Mikhaylov, A.; Lopatin, E. Blockchain Infrastructure and Growth of Global Power Consumption. Int. J. Energy Econ. Policy 2019, 9, 22-29. [CrossRef]

49. Denisova, V. Energy efficiency as a way to ecological safety: Evidence from Russia. Int. J. Energy Econ. Policy 2019, 9, 32-37. [CrossRef]

50. Lisin, A. Biofuel Energy in the Post-oil Era. Int. J. Energy Econ. Policy 2020, 10, 194-199. [CrossRef]

51. Lisin, A. Prospects and Challenges of Energy Cooperation between Russia and South Korea. Int. J. Energy Econ. Policy 2020, 10. [CrossRef]

52. Litvishko, O.; Veynberg, R.; Bodrov, I. Investment potential of the football industry. J. Phys. Educ. Sport 2019, 19, 2390-2399.

53. Litvishko, O.V.; Vyprikov, D.V.; Lubyshev, E.A. Financial and economic performance rating factors in national football industry. Teor. Prakt. Fiz. Kult. 2019, 11, 20-22.

54. Litvishko, V.S.; Litvishko, O.V. Environmental aspects of using microencapsulated malathion. Res. J. Pharm. Biol. Chem. Sci. 2019, 7, 3114-3122.

55. Lopatin, E. Methodological Approaches to Research Resource Saving Industrial Enterprises. Int. J. Energy Econ. Policy 2019, 9, 181-187. [CrossRef]

56. Lopatin, E. Assessment of Russian banking system performance and sustainability. Banks Bank Syst. 2019, 14, 202-211. [CrossRef]

57. Meynkhard, A. Priorities of Russian Energy Policy in Russian-Chinese Relations. Int. J. Energy Econ. Policy 2020, 10, 65-71. [CrossRef]

58. Meynkhard, A. Energy Efficient Development Model for Regions of the Russian Federation: Evidence of Crypto Mining. Int. J. Energy Econ. Policy 2019, 9, 16-21. [CrossRef]

59. Meynkhard, A. Fair market value of bitcoin: Halving effect. Invest. Manag. Financ. Innov. 2019, 16, 72-85. [CrossRef]

60. Nyangarika, A.; Mikhaylov, A.; Richter, U. Influence Oil Price towards Economic Indicators in Russia. Int. J. Energy Econ. Policy 2019, 9, 123-130. [CrossRef]

61. Nyangarika, A.; Mikhaylov, A.; Richter, U. Oil Price Factors: Forecasting on the Base of Modified Auto-regressive Integrated Moving Average Model. Int. J. Energy Econ. Policy 2019, 9, 149-160.

62. Nyangarika, A.; Mikhaylov, A.; Tang, B.-J. Correlation of Oil Prices and Gross Domestic Product in Oil Producing Countries. Int. J. Energy Econ. Policy 2018, 8, 42-48.

63. Shedenov, U.; Litvishko, O.; Kazbekov, B.; Suyunchaliyeva, M.; Kazbekova, K. Improvement of ecological tourism on the principles of sustainable economic development. E3S Web Conf. 2019, 135, 04047. [CrossRef]

64. Veynberg, R.; Popov, A. Engineering and development of business rules management systems as a part of intelligent DSS. Int. J. Appl. Eng. Res. 2016, 11, 1797-1802.

65. Veynberg, R.R.; Varfolomeeva, A.; Grigoryeva, K. Intelligent simulation models based on business rules approach in banking sector (WIP). Simul. Ser. 2015, 47, 397-402.

66. Veynberg, R.R.; Titov, V.A. Business Processes of Managing Media Assets: Technology and Practice of Implementation MAM-Class Systems. Adv. Sci. Lett. 2017, 25, 66-69. [CrossRef]

67. Zubakin, V.A.; Kosorukov, O.A.; Moiseev, N.A. Improvement of regression forecasting models. Mod. Appl. Sci. 2015, 9, 344-353. [CrossRef]

(C) 2020 by the authors. Licensee MDPI, Basel, Switzerland. This article is an open access article distributed under the terms and conditions of the Creative Commons Attribution (CC BY) license (http://creativecommons.org/licenses/by/4.0/). 